\title{
IAMJ
}

INTERNATIONAL

AYURVEDIC

MEDICAL JOURNAL

Case Report

ISSN: 23205091

Impact Factor: 5.34

\section{AN AYURVEDIC APPROACH FOR THE MANAGEMENT OF IDIOPATHIC ERYTHRO- CYTOSIS - A CASE REPORT}

\author{
Radhika. S. Pukale ${ }^{1}$, Harish Bhakuni², Virendra Singh Hada ${ }^{3}$ \\ ${ }^{1}$ P.G. Scholar, Final Year, ${ }^{2}$ Assistant Professor, ${ }^{3}$ P.G. Scholar; \\ P. G. Dept. of Kayachikitsa, National Institute of Ayurveda, Jaipur, Rajasthan, India
}

Email: radhika.s.pukale@gmail.com

\section{https://doi.org/10.46607/iamj410807332020}

(Published online: August 2020)

Open Access

(C) International Ayurvedic Medical Journal, India 2020

Article Received: 08/07/2020 - Peer Reviewed: 29/07/2020 - Accepted for Publication: 01/08/2020

(D) Check for updates

\begin{abstract}
An erythrocytosis occurs when there is an increased red-cell mass. The causes of erythrocytosis are divided into primary, when there is an intrinsic defect in the erythroid cell, and secondary, when the cause is extrinsic to the erythroid cell. An idiopathic erythrocytosis occurs when the increased red-cell mass has no identifiable cause. Primary and secondary defects can be further classified as either congenital or acquired causes. According to Ayurveda classics IE can be correlated as Rakta Pradoshaja Vikara due to Kapha Dushti leading to increased Picchilatwa (hyper viscosity) in Rakta. The present case study deals with chronic case of IE to stop the persistent increase of red blood cells mass \& viscosity of blood. In this case, an effort was made to treat 38 years old male patient presenting with headache, pain in heel, weakness, increased RBC mass, increased Hemoglobin \% with hyper viscosity in blood, was advised a regular medically prescription of phlebotomy every $8^{\text {th }}$ week since $3 y$ rs. This patients was treated with Shuddh Tamra Bhasma, Panchakola Choorna, Dashamoola Madhudak, Tab. Liv-52DS orally in BD Dose with Ushna Jala as Anupana. for a duration of 3months. During the treatment it was observed that patient showed much improvement in his symptoms, reports yielded $\mathrm{Hb} \%$ \& HCT (measure of hyper viscosity) maintained under normal limits.
\end{abstract}

Keywords: Rakta Pradoshaja Vikara, Shuddha Tamra Bhasma, Panchkola Choorna, Dasamoola Madhu Udak. 


\section{INTRODUCTION}

Erythrocytosis is an increase in the number of red blood cells. In a recent study, the prevalence of primary erythrocytosis (known as polycythemia vera) was 44-57 per $100000^{1}$. Erythrocytosis ${ }^{2}$ is suspected when hemoglobin is above $18.5 \mathrm{~g} / \mathrm{L}$ or the packed cell volume is greater than 0.52 in a man or $16.5 \mathrm{~g} / \mathrm{L}$ and 0.48 , respectively in a woman. Erythropoiesis is a tightly regulated process by which the bone marrow produces and maintains a normal red blood cell mass (RCM) required to provide adequate tissue oxygenation. The term 'idiopathic erythrocytosis' (IE) applies to a situation when a patient has a measured red cell mass (RCM) above the normal range, manifested as a persistent increase of venous hematocrit levels for 2 months. i.e. an absolute erythrocytosis, but-following further investigation, no cause of primary or secondary erythrocytosis/polycythemia can be established ${ }^{3}$. The condition has been variably called 'benign erythrocytosis' or 'pure erythrocytosis'. The term 'idiopathic erythrocytosis' is preferred because it emphasizes that the underlying cause, driving erythropoiesis is unknown. Most patients with an absolute erythrocytosis have an identifiable cause and can be classified into primary and secondary erythrocytosis $^{4}$ types based on the responsiveness of the erythroid progenitors to erythropoietin (Epo). Primary polycythemias are characterized by an autonomous and/or augmented response of the hematopoietic progenitors to Epo due to inherited germ line or acquired somatic mutations; this group includes PV. By contrast, secondary polycythemias have normal responsiveness of the erythroid progenitors to Epo and are due to increased levels of circulating factors driving erythropoiesis. Idiopathic Erythrocytosis constitutes the remaining group of patients in whom no cause for polycythemia has yet been identified.

Risk factors ${ }^{5}$ Patients at increased risk of occlusion, such as those with evidence of ischemia, previous history of thrombosis, peripheral vascular disease, diabetes mellitus and hypertension.

\section{Initial Investigations ${ }^{6}$}

CBC, Iron studies/ferritin Serum erythropoietin concentration JAK2 mutation, Oxygen saturations, Renal and liver profile, Abdominal ultrasound, Chest radiography, Lung functions, Bone marrow aspirate. Diagnostic criteria by $\mathrm{WHO}^{7}$ requires meeting both major criteria and 1 minor criterion or the first major criterion and 2 minor criteria.

Major Criteria include Hemoglobin $>18.5 \mathrm{~g} / \mathrm{dl}$ in men, $16.5 \mathrm{~g} / \mathrm{dl}$ in women, or other evidence of increased red cell volume with Presence of JAK2V617.

Minor Criteria includes Bone marrow biopsy showing hyper cellularity for age with trilineage growth with prominent erythroid, granulocytic, and megakaryocytic proliferation, Serum EPO level less than the reference range for normal, Endogenous erythroid colonies formation in vitro

Treatment Venesection/ Phlebotomy ${ }^{8}$ (usually 450 $\mathrm{mL}$ of blood; to maintain a target packed cell volume $<0.45$ ), together with Low Dose Aspirin (100 mg daily), is initial therapy that has been recently found to reduce the incidence of major vascular complications According to Ayurvedic literature, while explaining the importance of Rakta Dhatu, Acharya Charaka quotes rakta as prana (vital function) and further enlists Daurbalya (weakness), Agnisaad (generalized body weakness), Aruchi (tastelessness), Shirashoola (headache), Buddhisammoha (confusion) as classical features of Shonita pradoshaja vikara'. The Shuddha Rakta $^{10}$ is responsible for Bala (strength), Varna (complexion), Sukha (comfort), Ayushya i.e. enhances longevity (cha su 24/4) ${ }^{11}$ Acharya Sushruta has mentioned Rakta as Panchabhoutika, based on which it possess following Karma(functions) like Visrata (foul), Dravata (fluidity), Raga (redness), Spandan (Pulsation), Laghuta (lightness)- (Su.su 14/9). Amongst which specifically, the Drava Guna which is attributed to Jala mahabhuta when vitiates in Rakta along with kapha dosha \& ama leads to increased viscosity of blood.

Shleshma dushta rakta is Snigdha (unctuous), Sheetala (cold), Bahala (thick/increased volume), Picchila(increased viscosity), Chirasravi (increased resistance to blood flow) Ref-Su.su 14/21; Tantumadghanam (increased fibrinogen activity) Ref Cha.su.24/21 Similarly, the Acharyas have also mentioned, the Vriddha 
shonita dhatu (increased blood) is vitiated by kapha and leads to Bahalam (increase in volume), Picchila (increased viscous nature), Ghantwa (increased density) in Rakta. देहस्य रुधिरं मूलं रुधिरेणैव धार्यते | तस्माद्यत्नेन संरक्ष्यं रक्तं जीव इति स्थितिः || ४४||Su.su 14/44 Hence while planning Chikitsa for Rakta dushti by Kapha Dosha its very essential to protect Agni due to Rakta anavasthitata and treat the kapha dosha with Na ati Ushna Sheeta, Laghu Deepaniya, Pachana, Lekhana \& Chedana Guna Dravya with sufficient leveraging of vata-kapha axis equilibrium to avoid Vata Prakopa during Chikitsa. This case report aims at providing a cost effective and new approach towards successful management of Idiopathic erythrocytosis (IE) with effective and safe Ayurvedic formulation.

\section{Case Report}

38 years old male patient has attended the OPD in Department of Kayachikitsa, National Institute of Ayurveda, Jaipur. The patient had complaints related to Idiopathic Erythrocytosis which included headache, fatigue, pain in heels, weakness with his investigations as mentioned as follows. As in IE, due to continuous increase in RBC counts, hemoglobin $(\mathrm{Hb})$, Hematocrit (HCT) and considering the Kaphaja Rakta dushti; Laghu Deepaniya (improves metabolism), Chedana (dissolving/reducing the fibrinogenesis), Lekhaniya guna (scarping action) yukta oushadi were selected. These medicines mentioned in Table No 1 act on Yakrit \& Pleeha which is moola of Rakta dhatu were prescribed.

\section{Therapeutic intervention}

Table 1: Showing therapeutic intervention in a case of IE

\begin{tabular}{|l|l|l|l|}
\hline Oushadha Kalpana & Matra & Guna karma \\
\hline Shuddh Tamra Bhasma & $30 \mathrm{mgBD}$ & Oushadha & Tikta Kashaya, Ushna, Lekhana \\
\hline Panchakola Choorna & 2gm BD & Kala & Ushna, Deepana, Pachana \\
\hline Dashamoola Madhudak & $75 \mathrm{ml}+10 \mathrm{gm}$ & Vyana & Chedana, Lekhana \\
\hline Tab.Liv-52DS & 2-tab BD & Kala & Kaphapittapaha, Yakrit Uttejak \\
\hline
\end{tabular}

History of Present illness: Patient states that he was quite well 5 years back, Since then he has been suffering from Shirashoola (headache), Padashoola (pain in B/L feet), Daurbalya (generalized body weakness) for past $5 y$ rs which is relapsing and remitting in nature. The concerned physician treating his symptoms diagnosed the condition as i.e. based on his complete blood profile and initiated the primary treatment with phlebotomy (450 $\mathrm{ml}$ units of bloodletting) along with anticoagulant therapy with Ecospirin $75 \mathrm{mg}$ OD. On consecutive follow ups, the CBC (complete blood count) favoured an increase in the RBC mass along with regular prescribed treatment at the end of every two months, the patient could not get relief completely. As patient was not satisfied, he discontinued the medications. Further, the patient felt increase in the intensity of above-mentioned symptoms for about 2 months, after which he preferred visiting Out-patient department of NIA.
At the time of presentation, the patient was more concerned with headache, pain in feet, also with consistently increasing blood cell counts, PCV, HCT and its associated risks. Headache was of throbbing type perceived all over head triggered on lying down as well as on changing postures. Headache was associated with feeling of nausea \& fatigue. Pain in feet /heels increased on walking \& dropping down legs towards gravity. Patient didn't complain about any visual disturbances/vertigo/SOB/Nose bleeds. According to his family he did not snore or have any apneic periods during sleep. There was no history of smoking or any cardio-pulmonary disease and transfusion of blood products. The patient did not have a familial history of erythrocytosis.

Past history of Patient The patient had been suffering with similar symptoms for past 5 years, His family history revealed that there was no such pertinent manifestation of disorders. The following findings were observed on evaluation. 
Table 2: Showing previous Laboratory investigations

\begin{tabular}{|c|c|c|}
\hline $2 / 4 / 13$ & $\begin{array}{l}\text { USG (whole abdomen) -NAD } \\
\text { VIT B12- WNL } \\
\text { STOOL/E -NORMAL } \\
\text { LAP score -108 } \\
\text { PBF-normal }\end{array}$ & $\begin{array}{l}\text { HB- } 17.0 \mathrm{gm} \% \\
\text { RBC }-5.64 \text { million/cumm } \\
\text { MCV-86u } \\
\text { MCH-30pg } \\
\text { MCHC-35\% } \\
\text { Platelets- adequate } \\
\text { PCV-50.6\% }\end{array}$ \\
\hline $3 / 4 / 14$ & \multicolumn{2}{|l|}{$\begin{array}{l}\text { 2DEcho }-\mathrm{LVEF}=60 \% \\
\text { All chambers normal } \\
\text { IVS\&IAS intact }\end{array}$} \\
\hline 26/4/11 & \multicolumn{2}{|c|}{$\begin{array}{l}\text { EPO-15.5 (range } 3.7-29.5 \mathrm{Iu} / \mathrm{ml}) \\
\text { JAK2 Mutation- not detected }\end{array}$} \\
\hline $6 / 11 / 17$ & \multicolumn{2}{|c|}{ Bone marrow biopsy - Mildly Hyper-cellular marrow with adequate tri-lineage hematopoiesis } \\
\hline
\end{tabular}

\section{Roga-Rogi pariksha}

Probable Causative Factor could be Kshar (high alkaline food intake), Amla (Sour), Dadhi (curd), klinnabhakshana (improper food intake habits like frozen food/stale food), Atapa (excessive exposure to sunlight $\&$ to heat sources), Adhyashana (Eating excessive quantity of food frequently), Shrama (excessive labor/hard physical work) and presented premonitory symptoms like Ragata (redness of eyes), Agnisaada (Loss of appetite), Vyahat purishavega (disturbed bowel habits). The Symptomatology presented as Santapa (excessive feeling of hot flushes), Shirahshoola (headache), Padashoola (pain in heels), Atidaurbalya (excessive weakness), Tamaso darshana (blackouts), Buddhi sammoha (generalized anxiety). The symptoms aggravated on exposure to Atapa (sunlight/ heat radiating sources) which is anupashaya and were observed by the patient to be decreased on rakta avasechana (phlebotomy)- upashaya.

\section{Samprapti ghataka}

The predominance of doshas found as per symptomatology were observed to be due to Ati-guru, Picchila guna of Vikruta Kapha dosha along with prana-vyana vayu vikrati (abnormal functioning of prana vayu) leading to Sanga in Rakta vaha srotas. These vikruta dosha sanga, on further chronicity leads to khavaigunya in rakta dhatu due to improper functioning of rakta dhatvagni. The site of Udhbhavasthana (initiation of pathogenesis) was retracted to koshtha marga (yakrit, pliha) which is moola (primary site) for raktavaha srotos, disturbing the normal equilibrium of homeostasis. The cascade of pathogenesis is chirakari (prolonged) further progressing to sarvangashareera (throughout body with multisystem involvement) leads to manifestation of symptoms like Santapa (excessive feeling of hot flushes), Shirahshoola (headache), $\mathrm{Pa}$ dashoola (pain in heels), Atidaurbalya (excessive weakness), Tamaso darshana (blackouts), Buddhi sammoha (generalized anxiety).

\section{Astavidha rogi pareeksha}

Nadi was guru (heavy with high volume) and Pittakaphaja in nature, Mala was Saama, Shushka, with difficulty in passing and incomplete evacuation. Mutra (urine) was prakrit (normal quantity and frequency). $\mathrm{Ji}$ $h w a$ (tongue) was found to be Shwetabha (whitish) and Malavrita (coated). Patient was having normal body temperature but warm on touch (Ushna Sparsha) and his skin texture was Snigdha on touch. Shabda (voice quality) was Ruksha (rough). Examination of the Drik (eye) revealed prakrit drushti whereas Akriti (built) was madhyam (normal).

Personal history of patient: Appetite - Decreased; Bladder- Clear, Sleep- Normal; Addiction- None; Bowel- irregular, Diet- vegetarian

\section{Clinical Examination}

During examination patient was conscious, cooperative, fully oriented with intact short term and long-term memory. Patient exhibit his BMI $-19.6 \mathrm{~kg} / \mathrm{m}^{2}$ (height $175 \mathrm{~cm}$, weight - 60kg). Patient's pulse was Kaphavata dominant with a rate 76 beats/min, regular rhythm and 
high volume. Supine blood pressure was $130 / 80 \mathrm{mmHg}$ and in upright posture was $120 / 80 \mathrm{mmHg}$. Respiration was thoraco-abdominal in nature with rate $20 / \mathrm{min}$. Patient was having mild pallor, with no cyanosis, icterus, clubbing and dependent edema. Thyroid and different group of lymph nodes were not palpable. Cardio-Respiratory system examination was fairly normal with vesicular breathing. S1 \& S2 were clearly audible with normal rate and regular rhythm. There were no murmurs or gallops. During vascular assessment all peripheral pulses were palpable with no signs of poor peripheral circulation, no arterial bruits as well as venous hum were present. Neurological assessment showed intact superficial and deep sensation. On motor examination nutrition, tone, power was found to be normal and deep tendon reflexes.

\section{Timeline}

Table 3: Shows Timeline of Events Before and After Treatment

\begin{tabular}{|l|l|l|l|}
\hline Visit & Date & Complaints & Oral medication \\
\hline 1 & $2 / 4 / 19$ & $\begin{array}{l}\text { Loss of appetite /pain in heels with weakness } \\
\text { (when RBC /Hb increases) }\end{array}$ & $\begin{array}{l}\text { 1) Shuddh tamra bhasma 30mg Panchakola choorna 2 gm } \\
/ B D \\
\text { 2) Dashamoola madhudak (15gm dashamoola }+400 \mathrm{ml} \\
\text { water remains till } 75 \mathrm{ml}+10 \text { gm honey) } \\
\text { 3) Tab.Liv-52DS }\end{array}$ \\
\hline 2 & $23 / 4 / 19$ & Relief in previous symptoms & $\begin{array}{l}\text { 1) Shuddh tamra bhasma 30mg Panchakola choorna 2 gm } \\
\text { / BD } \\
\text { 2) Dashamoola madhudak (15gm dashamoola }+400 \mathrm{ml} \\
\text { water remains till 75 ml + 10 gm honey) } \\
\text { 3) Tab.Liv-52DS }\end{array}$
\end{tabular}

\section{Results}

\section{Table 4: Showing improvements in Investigations}

\begin{tabular}{|c|c|c|}
\hline Sr.No & Date & Complete Blood Count \\
\hline 1 & $19 / 2 / 19$ & $\begin{array}{l}\mathrm{Hb}-16.7 \mathrm{gm} \% \\
\mathrm{RBC}-6.10 \mathrm{million} / \text { cumm } \\
\mathrm{Hct}-54.1 \% \\
\mathrm{MCV}-85.4 \mathrm{fl} \\
\mathrm{MCH}-27.4 \mathrm{pg} / \mathrm{ml} \\
\mathrm{MCHC}-32.1 \mathrm{~g} / \mathrm{dl} \\
\text { Basophils- } 0.8 \%\end{array}$ \\
\hline 2 & $22 / 4 / 19$ & $\begin{array}{l}\text { RBC-5.76 million /cumm } \\
\mathrm{Hb}-15 \mathrm{gm} \% \\
\mathrm{MCV}-82.8 \mathrm{fl} \\
\mathrm{MCH}-26.0 \mathrm{pg} / \mathrm{ml} \\
\mathrm{MCHC}-31.4 \mathrm{~g} / \mathrm{dl} \\
\mathrm{Hct}-47.7 \% \\
\text { Basophils } 0.6 \%\end{array}$ \\
\hline
\end{tabular}

There was marked and rapid improvement in his symptoms and wellbeing without phlebotomy \& anticoagulant therapies in duration of two months. There was marked and rapid improvement in following investigations as shown in Table no 3

\section{DISCUSSION}

In this study, due to hyper viscosity i.e. Picchilata (viscous) and Ghanatwa (increased density) of Rakta is due to Kapha dusti in Raktadhatu. The treatment protocol followed was na ati ushna sheeta, Laghu Deepaniya 
and hence the drugs needed to treat this must have, $\mathrm{Pa}$ chana (enhancing proper metabolism), Lekhana (scraping) \& Chedana (dissolving clots) guna. So, the choice of drug was Shuddha tamra bhasma 30mg with combination of Panchkola choorna in Vyana kala with Ushna jala anupana. According to Ayurveda Prakash \& Rasamrit $^{12}$ Shuddha Tamra (purified copper) is considered as Tikta- kashaya rasa (astringent), Ushna veerya, Madhura vipaka, Laghu, Lekhana \& Saram. These properties are Pittakapha hara, also acts on Rakta dhatwagni normalizing the Prakrit karma of Rakta dhatu. According to Rasachudamshu, Shuddha tamra is considered as "Param Lekhaniyam" (scraping effect), due to which the risk of thrombotic events was reduced down and ushna veerya helps in normalizing the hyper-viscous nature of blood.

Panchakola churna consists of Pippali (Piper longum Linn.) Pippalimula (Root of the Piper longum Linn.), Chavya (Piper chaba Hunter), Chitraka (Plumbago zeylanica Linn.) and Sunthi (Zingiber officinale Roscoe) are the ingredients of Panchakola Churna. All the ingredients have Laghu, Ruksha and Sukshma

Gunas, Ushna Virya, Katu Rasa, KatuVipaka and Pachana, Kaphahara properties. Rasa and Vipaka of

the Panchakola are Katu, helpful in Agnidipana and Pachana. Thus, it becomes clear that Deepana \& kaphahara properties correct Agnivaishamya and Doshavikriti. After the proper channelization of Rasadi Dhatu Samvahana, Rakta vikriti with kapha was checked maintaining Swasthya which entitles "Samagni, Samadhatu” (maintaining health) axis. Liv. $52^{13}$ DS Tablet is manufactured by Himalaya Drug Company and it contains a number of active ingredients including Himsra (Capparis spinosa), Kasani (Cichorium intybus), Mandura bhasma, Kakamachi (solanum nigrum), Arjuna (Terminalia arjuna), Kasamarda (Cassia occidentalis), Biranjasipha (Achillea millefolium), Jhavuka (Tamarix gallica) acts on yakrit and pliha which is rakta vah srotas moola and is responsible for Pachana (metabolism \& excretion) of Ama (toxins) leading to Kapha shaman, enhancing the Prakrit drava (fluidity), sara (free flowing nature) guna of raktashrit pitta. Dashamoola Madhu udaka - Dasha- moola ${ }^{14}$ is useful herbal combination of laghu panchamoola i.e. Gokshura (Tribulus terrestris), Shalaparni (Desmodium gangeticum), Prishniparni (Urariapicta), Kantakari (Solanum xanthocarpum) and Bruhati (Solanum indicum) and Bruhat panchamoola i.e. Bilva (Aegle marmelos), Agnimantha (Premna integrifolia), Shyonak (Oroxylum indicum), Gambhari (Gmelina arborea) and Patala (Stereospermum suaveolens). Laghupanchamoola indicated for VataPitta disorders and Bruhatpanchamoola is indicated in Vata-Kapha disorders. Dashamoola is Vatananuloma, Tridoshanashak Madhu (honey) is Ruksha, Kashaya, Chedhana, Sukshma marga anusari, Ropana, Raktapittakaphapaha. Yogavahi guna is enriched with enzymatic properties helps in enhancing the effects of Dashamoola increasing Lekhana karma. Due to the Grahi effect of Dashamoola the Prakshepa of Madhu in it will help to counteract the effect and acts as Amapachana (enhances metabolism), Bhedana (dissolving the hyperdensity \& hyper viscosity), Anulomana (normalizes the functions of $V a y u$ ).

\section{CONCLUSION}

Marked improvement was found in all the signs and symptoms of the disease. After completion of treatment there is maintenance of proper blood counts without any complication or adverse effects and was beneficial in terms of cost effectiveness It is an effort to understand the concept of Shonitapradoshaja vikara w.s.r. to Kaphadusti in Rakta with a view of applied aspects of Idiopathic erythrocytosis.

\section{REFERENCES}

1. McMullin M. F. (2012). Diagnosis and management of congenital and idiopathic erythrocytosis. Therapeutic advances in hematology, 3(6), 391-398. https://doi.org/10.1177/2040620712458947

2. Pearson TC \& Messinezy M. Idiopathic eryhtrocytosis, diagnosis and clinical management. Pathology-Biology 2001; 49: 170-177

3. Modan B \& Modan M. Benign erythrocytosis. British Journal of Haematoloy 1968; 14: 375-381

4. Najean Y, Triebel F \& Dresch C. Pure erythrocytosis: reappraisal of a study of 51 cases. American Journal of Hematology 1981; 10: 129-136 
5. Blacklock HA \& Royle GA. Idiopathic erythrocytosisa declining entity. British Journal of Haematology 2001; 115: 774-781.

6. T.C. Pearson, M. Messinezy, N. Westwood, A polycythemia vera update: diagnosis, pathobiology and treatment. In: Hematology ASH Education Program Book, 2000, p. 51-68

7. Spivak JL, Silver RT. The revised World Health Organization diagnostic criteria for polycythemia vera, essential thrombocytosis, and primary myelofibrosis: an alternative proposal. Blood 2008;112(2):231-9

8. British Committee for Standards in Haematology (www.bcshguidelines.com) - Guidelines for the diagnosis, investigation, and management of hematological diseases, including polycythaemia and erythrocytosis

9. Agnivesa's Caraka Samhita Text Revised by Caraka and Drdhbala, Introduction by Shri Satya Narayana Sastri by Pt. Kashinatha Sastri, Dr. Gorakha Natha Chaturvedi, Part I, Published by Choukhamba Bharati Academy, Varaansi, Reprint, Sutrasthana, Chapter 24, Slok no 510, 2011, 619 .

10. Agnivesa's Caraka Samhita Text Revised by Caraka and Drdhbala, Introduction by Shri Satya Narayana Sastri by Pt. Kashinatha Sastri, Dr. Gorakha Natha Chaturvedi, Part I, Published by Choukhamba Bharati Academy, Varaansi, Reprint, Sutra Sthana, Chapter 24, Slok no 13, 2011,620 .
11. तद्विशुद्धं हि रुधिरं बलवर्णसुखायुषा| युनक्ति प्राणिनं प्राणः शोणितं ह्यनुवर्तते||४||Cha.su 24/4

12. Rasaamritam by Dr. Devnath Singh Gautam, Published by Chaukhambha Surbharati Prakashana, Varanasi, First Edition, Ratnavigyaniya Adhyaya, Chapter 8; 2008, 103-104

13. Santanu Ghosh, D P Singh.International Journal of Current Research and Academic Review Evaluation of safety and efficacy of a Polyherbal formulation Liv. 52 DS in the Management of Non-Alcoholic Steatohepatitis (NASH): An open clinical study ISSN: 2347-3215 Volume 2 Number 9 (September-2014) pp. 305-316

14. Bhavmishra, Bhavaprakashsamhita, edited by Pandit Shri Brahma Sankar Mishra with the Vidyotani Hindi Commentary, Chaukhambha Sanskrit Samsthan, Varanasi, 9th Edition 2005

\section{Source of Support: Nil Conflict of Interest: None Declared}

How to cite this URL: Radhika. S. Pukale et al: An Ayurvedic Approach For The Management Of Idiopathic Erythrocytosis - A Case Report. International Ayurvedic Medical Journal \{online\} 2020 \{cited September, 2020\} Available from: http:/www.iamj.in/posts/images/upload/4549 4555.pdf 